\title{
The Use of Earthworm Eudrilus eugeniae in the Breakdown and Management of Poultry Waste
}

\author{
Nirmala Natarajan ${ }^{1}$, K.S. Nirmala Devi ${ }^{1}$ \\ ${ }^{I}$ Research Department of Zoology, Periyar E.V.R. College (Autonomous), Tiruchirappalli, Tamil Nadu, India.
}

\begin{abstract}
Pot culture experiments were done to process poultry waste mixed with bedding materials (Eichhornia crassipes and cow dung) in the ratio of 1:1:2, 1:2:1 and 2:1:1 using earthworm Eudrilus eugeniae. Totally there were three treatments $\left(T_{1}, T_{2}\right.$ and $\left.T_{3}\right)$ with three replicates for each. The raw poultry waste, predigested poultry waste and vermicompost were separately subjected to chemical nutrients composition analysis. The vermicompost had increased levels of total $N, P, K$ and Ca when compared to raw poultry waste and pre-digested poultry waste. The results of the present study suggest that the vermicomposted poultry waste with Eichhornia crassipes and cow dung at 2:1:1 proportion can very well be used as organic manure.
\end{abstract}

Keywords: Earthworm, Poultry waste, Eichhornia crassipes, Vermicompost, Biomass.

\section{Introduction}

Poultry litter is usually applied as a fertilizer. Excessive land application of poultry litter can lead to surface water runoff of plant nutrients, which in turn can cause eutrophication of water reservoirs. Transportation of poultry litter out of the affected areas may decrease the negative environmental effects related to its land application; however, high transportation costs require adding value to poultry litter.

Vermicomposting can potentially add value to poultry litter. Vermicomposting involves consumption and stabilization of organic matter by earthworms. Vermicomposting of poultry litter can not only produce value added fertilizer but it can also produce worms which could be sold as fish bait and a protein source. Although several studies have been conducted on vermicomposting, limited available data presents numerous challenges while vermicomposting poultry litter. High ammoniacal-nitrogen concentration, auto heating, and high bulk density are some of the major concerns that need to be addressed while vermicomposting poultry litter.

Eichhornia is the free floating invasive aquatic macrophytes that are known to cause severe damage to the aquatic habitat. Literature revealed that the noxious weeds like Eichhornia are resisted to the all physical, chemical, biological as well as hybrid methods that have been applied to eradicate it [1]. Eichhornia is commonly found in India and it is a problematic weed in a number of districts. It has choked hundred of water bodies in India. Ecologically devastating properties of Eichhornia can be profitably used as compost after as conversion by vermicompost [2]. The vermicomposting process is a result of the combined action of the earthworms and microflora living in earthworm intestines and in the growth medium. Vermicompost improve the soil structure, increasing the water holding capacity and porosity which facilitate the root respiration and growth $[3,4]$.

\subsection{Collection and processing}

\section{Materials and Methods}

In present study Eichhornia was utilized for composting. Aquatic weed Eichhornia was collected from the river of Uyyakondan, Trichy, Tamil Nadu. The Eichhornia was allowed to dry slightly in sunlight and was chopped into small bits. Poultry waste was purchased from a Poultry farm, Namakkal, Tamil Nadu. Cow dung (CD) produced from the Jaya Cowshed, Tiruchirappalli, India, served as feed. The earthworms Eudrilus eugeniae were purchased from Nehru Memorial College, Puthanampatti, Trichy and culture was maintained and utilized for future studies. The earthworms were reared in garden soil and garden waste, vermibed of dimension $4 \times 2 \times 4 / 4$ feet (length $\times$ breadth $\times$ height) sufficient for 2,000 to 3,000 worms with controlled moisture 35$45 \%$ and temperature $26^{\circ} \mathrm{C}-28^{\circ} \mathrm{C}$.

\subsection{Experimental setup}

The earthworms were acclimatized to the laboratory conditions for a period of 15 days before the commencement of the experiment. They were put in groups into earthen pots of $5 \mathrm{~kg}$ capacity. Ten pots were taken for the experiment. The pots were marked as $T_{1}, T_{2}, T_{3}$ and control. Each earthen pot was having a small pore at the bottom to drain excess water. Poultry waste, Eichhornia and cow dung were taken in the following combinations. 


$\begin{array}{cccccc}\text { Poultry waste } & + & \text { Eichhornia } & + & \text { Cow dung } & \\ 1 & : & 1 & : & 2 & \text { (T1) } \\ 1 & : & 2 & : & 1 & \text { (T2) } \\ 2 & : & 1 & : & 1 & \text { (T3) }\end{array}$

\subsection{Vermibed preparation}

From the predigested materials of poultry waste, leaf litter Eichhornia and cowdung was taken in different ratio, separately in ten earthen pots. Twenty five earthworm species of E.eugeniae respectively were introduced separately. The temperature and moisture was maintained by sprinkling water at regular intervals for a period of 45 days and kept in undisturbed place.

\subsection{Soil analysis}

Soil sample collected horizon wise powdered with wooden mallet and passed through a $2 \mathrm{~mm}$ sieve and utilized for analysis. Soil sample analysis was done before and after the experiment by following standard methods. The $\mathrm{pH}$ was measured using digital $\mathrm{pH}$ meter in $1 / 10(\mathrm{w} / \mathrm{v})$ aqueous solution. Total Organic Carbon (TOC) was determined by the partial-oxidation method [5]. Total Nitrogen (TN) was measured by micro Kjeldahl method [6]. Total extractable Phosphorus (TP) was determined by using Olsen'sodium bicarbonate extraction method [7], $\mathrm{K}, \mathrm{Ca}$ and $\mathrm{Mg}$ were determined after extraction of the sample using ammonium acetate extractable method [8] and the samples were analyzed by Perkin Elmer AA-6300, double beam Atomic Absorption Spectrophotometer (AAS).

\subsection{Growth of Eudrilus eugeniae}

\section{Results And Discussion}

The vermicompost was dark brown in colour and homogeneous after 45 days of earthworm's activity. The changes in worm biomass for all the treatments over the experimentation period are illustrated in Table 1. At the end of the 45 days, the earthworm biomass had increased in all the treatments. In general, the maximum biomass gain was recorded in T1 $(38.866 \pm 1.499 \mathrm{mg} /$ worm $)$ and T2 $(37.736 \pm 1.114 \mathrm{mg} /$ worm $)$ treatments.

Similarly, the maximum growth rate was achieved in $\mathrm{T}_{1}(38.866 \pm 1.499 \mathrm{mg} / \mathrm{worm})$ and $\mathrm{T}_{2}(37.736 \pm$ $1.114 \mathrm{mg} /$ worm) than the other treatments. There was no statistical significant difference among $\mathrm{T}_{1}$ and $\mathrm{T}_{2}$ treatments for biomass gained per worm $(\mathrm{P}<0.05)$. The growth rate has been considered as a good comparative index to compare the growth of earthworms in different ratio [9]. In the present study addition of CD and Eichhornia in the substrates resulted in an increase in biomass of E.eugeniae. Growth and reproduction in earthworms require OC, $\mathrm{N}$ and $\mathrm{P}$ which are obtained from litter, grit and microbes [10]. The higher nitrogen $(1.6 \%)$ and phosphorus $(2.5 \%)$ content of press mud to support better growth length and biomass [11].

Table -1 Growth of E. eugeniae in different treatment

\begin{tabular}{|c|c|c|c|c|}
\hline S.No & Treatment & No. of Earthworms & Initial weight of Earthworms & Final weight of Earthworms \\
\hline 1 & Control & 25 & $27.553 \pm 0.042$ & $33.080 \pm 0.208$ \\
\hline 2 & $\mathrm{~T}_{1}$ & 25 & $28.403 \pm 0.224$ & $38.866 \pm 1.499$ \\
\hline 3 & $\mathrm{~T}_{2}$ & 25 & $28.383 \pm 0.585$ & $37.736 \pm 1.114$ \\
\hline 4 & $\mathrm{~T}_{3}$ & 25 & $28.646 \pm 0.703$ & $36.116 \pm 1.075$ \\
\hline
\end{tabular}

Significant at the 0.05 level, $\mathrm{F}=17.833, \mathrm{P}$ Value $<0.001$.

\subsection{Physicochemical properties of poultry waste}

The magnitude of various chemical parameters of raw poultry waste, pre-digested poultry waste and vermicompost are given in Table 2. An increase in the values was observed in the following parameters such as total $\mathrm{N}, \mathrm{P}, \mathrm{K}$ and $\mathrm{Ca}$ in the pre-digested poultry waste when compared to raw poultry waste. In contrast, a decreasing trend in the values was observed in $\mathrm{pH}, \mathrm{EC}$ and $\mathrm{OC}$ in the pre-digested poultry waste when compared to raw poultry waste (Table 2 ).

Table-2 Analysis of macro and micro nutrients in the sample of poultry waste with Eichhornia and Cow dung before and after treatment

\begin{tabular}{|c|c|c|c|c|c|c|c|c|}
\hline \multirow[b]{2}{*}{ S.No } & \multirow[b]{2}{*}{ Parameters } & \multirow{2}{*}{$\begin{array}{c}\text { Raw } \\
\text { Poultry } \\
\text { waste }\end{array}$} & \multicolumn{3}{|c|}{ Before treatment in Poultry waste } & \multicolumn{3}{|c|}{ After treatment in Poultry waste } \\
\hline & & & $\begin{array}{l}\mathrm{P}+\mathrm{E}+\mathrm{C} \\
1: 1: 2\end{array}$ & $\begin{array}{l}P+E+C \\
1: 2: 1\end{array}$ & $\begin{array}{l}P+E+C \\
2: 1: 1\end{array}$ & $\begin{array}{l}P+E+C \\
1: 1: 2\end{array}$ & $\begin{array}{l}P+E+C \\
1: 2: 1\end{array}$ & $\begin{array}{l}P+E+C \\
2: 1: 1\end{array}$ \\
\hline 1 & $\mathrm{pH}$ & 8.09 & 7.68 & 7.84 & 7.77 & 7.31 & 7.69 & 7.61 \\
\hline 2 & $\mathrm{EC} \mathrm{dSm}^{-1}$ & 0.26 & 0.34 & 0.34 & 0.31 & 0.54 & 0.59 & 0.42 \\
\hline 3 & Organic Carbon (\%) & 0.85 & 0.84 & 0.83 & 0.80 & 0.82 & 0.74 & 0.79 \\
\hline 4 & Total Nitrogen $(\%)$ & 3.20 & 3.80 & 3.45 & 3.50 & 4.22 & 3.68 & 3.71 \\
\hline 5 & Total Phosphorus (\%) & 0.15 & 0.19 & 0.20 & 0.25 & 0.26 & 0.27 & 0.27 \\
\hline 6 & Total Potassium (\%) & 0.80 & 1.45 & 1.38 & 1.27 & 3.84 & 3.16 & 3.61 \\
\hline
\end{tabular}


The Use of Earthworm Eudrilus eugeniae in the Breakdown and Management of Poultry Waste

\begin{tabular}{|c|l|c|c|c|c|c|c|c|}
\hline 7 & Total Calcium (\%) & 9.70 & 9.46 & 10.14 & 10.19 & 10.60 & 10.10 & 14.70 \\
\hline 8 & Total Magnesium (\%) & 4.80 & 3.80 & 4.60 & 4.40 & 2.90 & 5.80 & 6.10 \\
\hline 9 & Manganese (ppm) & 0.81 & 0.68 & 0.60 & 0.44 & 0.64 & 0.46 & 0.72 \\
\hline 10 & Zinc (ppm) & 0.46 & 0.17 & 0.15 & 0.31 & 0.23 & 0.47 & 0.43 \\
\hline 11 & Copper (ppm) & 0.61 & 0.98 & 0.67 & 0.89 & 0.46 & 0.91 & 0.92 \\
\hline 12 & Iron (ppm) & 15.60 & 37.00 & 9.30 & 29.80 & 18.11 & 12.46 & 14.16 \\
\hline
\end{tabular}

It is obvious from the results that the vermicompost had comparatively higher quantities of total $\mathrm{N}, \mathrm{P}$, $\mathrm{K}$ and $\mathrm{Ca}$ than the raw poultry waste; and lower quantities of $\mathrm{pH}, \mathrm{EC}$, and $\mathrm{OC}$ than the raw poultry waste. The $\mathrm{pH}$ values appeared to vary a little bit between pre-digested poultry waste and vermicompost. An increasing trend was observed in the parameters viz., total N, P, K and Ca ratio in the vermicompost when compared to predigested poultry waste. On the other hand, the values of $\mathrm{OC}, \mathrm{Mn}, \mathrm{Zn}$ and $\mathrm{Mg}$ were comparatively higher in vermicompost than the pre-digested poultry waste (Table 2). In this study, a reduction in the $\mathrm{pH}$ was recorded at the end of the experiment. The variability in $\mathrm{pH}$ could be due to the production of $\mathrm{CO}_{2}$ and organic acids during organic waste decomposition. During their study on the vermicomposting of some organic residues concluded that the lowered $\mathrm{pH}$ level at the end might be due to the production of $\mathrm{CO}_{2}$ and organic acids by microbial decomposition during the process of bioconversion of different substrates in the beds [12]. The shifting of $\mathrm{pH}$ to lower levels could be attributed to mineralization of nitrogen and orthophosphates and bioconversion of organic materials into intermediate products such as organic acids [13].

A decrease in the electrical conductivity values in vermicompost may be due to the presence of exchangeable $\mathrm{Ca}, \mathrm{Mg}$ and $\mathrm{K}$. In general, Organic Carbon loss has been observed during the vermicomposting process [14 -17]. Earthworm modifies substrate conditions, which consequently affects carbon losses from the substrates through microbial respiration in the form of $\mathrm{CO}_{2}$ and even through mineralization of organic matter. A large fraction of organic matter in the initial substrates was lost as $\mathrm{CO}_{2}$ by the end of the vermicomposting period. The vermicomposted material had greater nitrogen content [18]. The inoculation of worms in waste material considerably enhances the amount of $\mathrm{N}$ due to earthworm mediated nitrogen mineralization of wastes. It also suggested that the earthworm enhances the nitrogen levels of the substrate by adding its excretory products, mucus, body fluid, enzymes and even through the decaying tissues of dead worms in vermicomposting sub-system [17].

The passage of organic residue through the gut of earthworm, results in phosphorous converted to forms, which are available to plants [18]. The release of phosphorous in available form is performed partly by earthworm gut phosphatases, and further release of $\mathrm{P}$ might be attributed to the P-solubilizing microorganisms present in worm casts. The earthworm mediated phosphatase enhancement in soils [19]. The present study concluded that the poultry waste at 2:1:1 concentration can be utilized for vermicomposting by using epigeic earthworm E. eugeniae. The vermicompost thus prepared is found to possess desirable nutrients at desired levels such as $\mathrm{pH}$ (range 6.5 - 7.5), total nitrogen as hence it can be used for crop production and maintenance of soil fertility [20]. In the present study, the time taken for the bioconversion of poultry waste into vermicompost was 45 days. Research work is required in order to find out a method in which the bioconversion of these waste will be completed in about 25-30 days or even a lesser than this time limit. Research works may also be carried out with different combinations of the selected wastes for the production of vermicompost and to find out its nutrients status.

\section{Conclusion}

The percentage of TN showed the increasing order in all treatment. It is suggested that along with nitrogen releasing mucus and by accumulating excretory products, body fluids and other biological fluids rich in nitrogen. The species of $\mathrm{E}$. eugeniae exhibit better in converting the waste and increasing the percentage of NPK. Vermicomposting could be applied as an alternative technology for the management of poultry waste. The suitability of the vermicompost produced as an organic fertilizer was confirmed by having an ideal $\mathrm{pH}$, total organic carbon and the increase in humic acid content. The present study suggested that the addition of Eichhornia, cow dung based vermicompost contributed to the enrichment in total and available N, P, K and Ca. The treatment of $T_{3}$ enhanced the nutrient contents in Vermicomposting; hence, value was added to the quality of the vermicompost.

\section{Acknowledgements}

The authors thanks the Principal, Periyar E.V.R College (Autonomous), Tiruchirappalli, TamilNadu, India for the encouragement and providing facilities for the study. 


\section{References}

[1] S.A. Abbasi, and E.V. Ramaswamy, In: Biotechnological Methods of Pollution Control, Orient Longman (Universities press India Ltd, Hyderabad, 1999).

[2] N. Kannadasan, Nirmala Natarajan, N. Anbusaravanan, P. Sekar, and R. Krishnamoorthy, Assessment of sustainable vermiconversion of water hyacinth by Eudrilus eugeniae and Eisenia fetida J. Appl. \& Nat. Sci. 5 (2), 2013, $451-454$.

[3] K. E. Lee, Some trends opportunities in earthworm research or: Darwin's children. The future of our discipline, J. Soil Biol. Biochem., 24 (12), 1992, 1765-1771.

[4] K. Parthasarathi, M. Balamurugan, and L.S. Ranganathan, Influence of vermicompost on the physic-chemical and biological properties in different types of soil along with yield and quality of the pulse crop-blackgram. J. Environ. Health Sci. Eng., 5 (1), 2008, 51-58.

[5] A. Walkley, and I.A. Black, An examination of the degtjareff method for determining soil organic matter and prepared modification of the chronic acid titration method. J. Soil Science, 4, 1934, 29-38.

[6] M.L. Jackson, Soil chemical analysis (Prentice Hall of India Private Limited, New Delhi.1973).

[7] S.R. Olsen, C.V. Cole, F.S. Watanabe, and L.A. Dean, Estimation of available phosphorus in soil by extraction with sodium bicarbonate (Circulation of US Department of Agriculture,1954).

[8] R.R. Simard, Ammonium acetate extractable elements In: soil sampling and methods of analysis (Eds: Martin.R and Carter. S.Lewis publisher FL USA.1993), 38-43.

[9] C.A. Edwards, J. Dominguez, and E.F. Neuhauser, Growth and reproduction of Perionyx excavatus (Perr.) (Megascolecidae) as factors in organic waste management, J.Biol. Fert. Soils. 27, 1998, 155-161.

[10] C.A. Edwards, and P.J. Bohlen, Biology and Ecology of Earthworms, (3rd ed.), (Chapman and Hall, London. 1995).

[11] K. Parthasarathi, and L.S. Ranganathan, Longivity of microbial and enzyme activity and their influence on NPK content in pressmud vermicasts, Eur. J. Soil Biol. 35, 1999,107-113.

[12] J. Haimi, and V. Huhta, Capacity of various organic residues to support adequate earthworm biomass for vermicomposting. Biol. Fert. Soils 2, 1986, 23-27.

[13] P.M. Ndegwa, S.A. Thompson, and K.C. Das, Effects of stocking density and feeding rate on vermicomposting of biosolids. J.Biores. Tech., 71, 2000, 5-12.

[14] R.K. Bhatnagar, and R.K. Palta, Earthworm:Vermiculture and vermicomposting. (Kalyani Publishers, NewDelhi. 1996).

[15] R.D. Kale, K. Bano and R.V. Krishnamoorthy, Potential of Perionyx excavatus for utilizing organic wastes. Pedobiologia, 23, 1982, 419-425.

[16] C. Elvira, L. Sampedro, E. Benitez and R.Nogales, Vermicomposting of sludges from paper mill and dairy industries with Eisenia andrei: A pilot scale study. J. Biores. Technol, 63, 1998, 205-211.

[17] S. Suthar, Influence of different food sources on growth and reproduction performance of composting epigeics: Eudrilus eugeniae, Perionyx excavatus and Perionyx sansibaricus, Appl. Ecol. Environ. Res., 5(2), 2007a, 79 - 92.

[18] K.E. Lee, Some trends opportunities in earthworm research or: Darwin'schildren. The future of our discipline. 1992. J.Soil Biol. Biochem., 24, 1992, 1765-1771.

[19] R.C. Le Bayon, and F. Binet, Earthworm changes the distribution and availability of phosphorus in organic substrates, J. Soil Biol. Biochem, 38, 2006, 235-246.

[20] Tandon, HLS (Ed.), Methods of Analysis of Soils, Plants, Waters, Ferrtilizers and Organic Manures. Fertiliser Development and Consultation Organization, New Delhi, India, 2005, 204. 